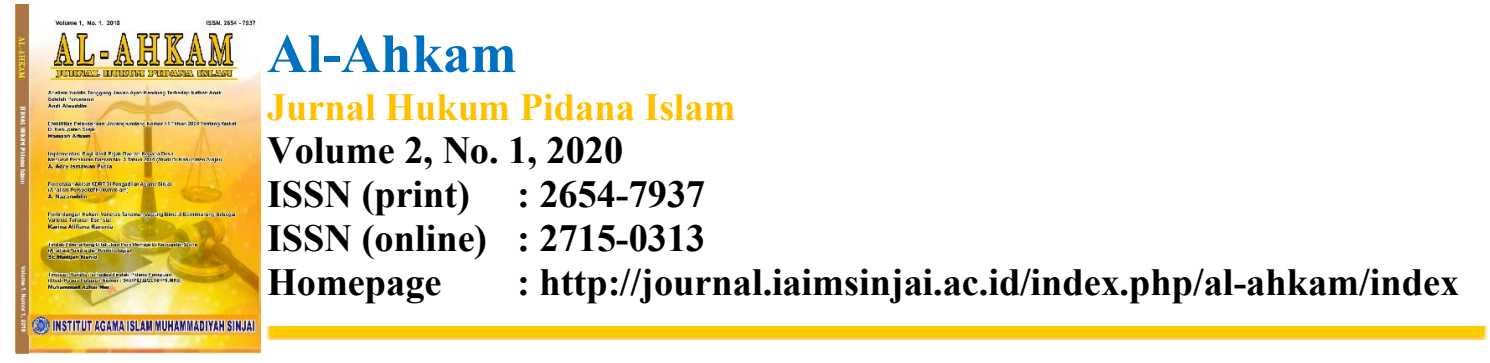

\title{
PERLINDUNGAN HUKUM TERHADAP TERSANGKA ANAK DALAM PROSES PENYIDIKAN DI KEPOLISIAN RESOR POHUWATO
}

\author{
Muhammad Rizal Lampatta ${ }^{1}$, Irham Yasir ${ }^{2}$ \\ ${ }^{1}$ Universitas Pohuwato, Jl. Trans Sulawesi No. 147 Marisa \\ ${ }^{2}$ Kepolisian Resor Pohuwato, Jl. Trans Sulawesi Marisa \\ E-mail:rlampatta@gmail.com Tlp.082396449938
}

\begin{abstract}
Abstrak
Tujuan dalam penelitian ini adalah untuk mengetahui pelaksanaan perlindungan anak sebagai tersangka dalam proses penyidikan di Polres Pohuwato dan untuk mengetahui menjadi kendala dalam pelaksanaan perlindungan anak sebagai tersangka dalam proses penyidikan di Polres Pohuwato. Metode penelitian yang digunakan adalah menggunakan metode penelitian hukum empirik. Hasil penelitian ini yaitu (1) Pelaksanaan perlindungan anak sebagai tersangka dalam proses penyidikan di Polres Pohuwato adalah dengan tetap melaksanakan amanat Undang - Undang Sistem Peradilan Anak dan Undang - Undang Perlindungan Anak. Pada tahap penyidikan anak yang melakukan tindak pidana apabila melakukan tindak pidana yang memungkinkan unntuk dilakukan penangkapan dan penahanan maka upaya tersebut akan dilakukan. Dalam proses penyidikan upaya diversi dan ADR akan terus dilaksanakan selama para korban mau memberikan maaf dan menyepakati perdamaian. (2) Kendala dalam pelaksanaan perlindungan anak sebagai tersangka dalam proses penyidikan di Polres Pohuwato yaitu Belum adanya BAPAS di Kabupaten Pohuwato, Masih terdapat Penyidik UPPA yg belum mendapat pelatihan khusus, Rutan negara khusus untuk tersangka anak yang sampai saat sekarang ini belum ada.Saran dalam penelitian ini adalah Pemerintah perlu menyediakan BAPAS dan Pembimbing Kemasyarakatan di wilayah kabupaten Pohuwato agar memudahkan koordinasi dalam pelaksanaan diversi melalui mediasi penal terhadap Anak yang berhadapan dengan hukum
\end{abstract}

Kata Kunci : Perlindungan Hukum, Anak, Penyidikan

\begin{abstract}
The purpose of this study was to determine the implementation of child protection as a suspect in the investigation process at the Pohuwato Regional Police Station and to find out to be an obstacle in the implementation of child protection as a suspect in the investigation process at the Pohuwato Regional Police Station. The research method used is to use empirical legal research methods. The results of this study are (1) The implementation of child protection as a suspect in the investigation process at the Pohuwato Police Station is by continuing to carry out the mandate of the Law System for the Juvenile Justice System and the Child Protection Act. At the stage of the investigation of a child who commits a crime if committing a criminal offense that is possible for an arrest and detention, such efforts will be made. In the investigation process the diversionary effort and ADR will continue as long as the victims are willing to apologize and agree on peace. (2) Obstacles in the implementation of child protection as a suspect in the investigation process at the Pohuwato Police Station namely the absence of BAPAS in Pohuwato District, there are still UPPA Investigators who have not received special training, a special state detention center for child suspects which until now has not yet existed. this research is the Government needs to provide BAPAS and Community Guidance in the Pohuwato district area in order to facilitate coordination in the implementation of diversion through mediating the penalties against children in conflict with the law
\end{abstract}




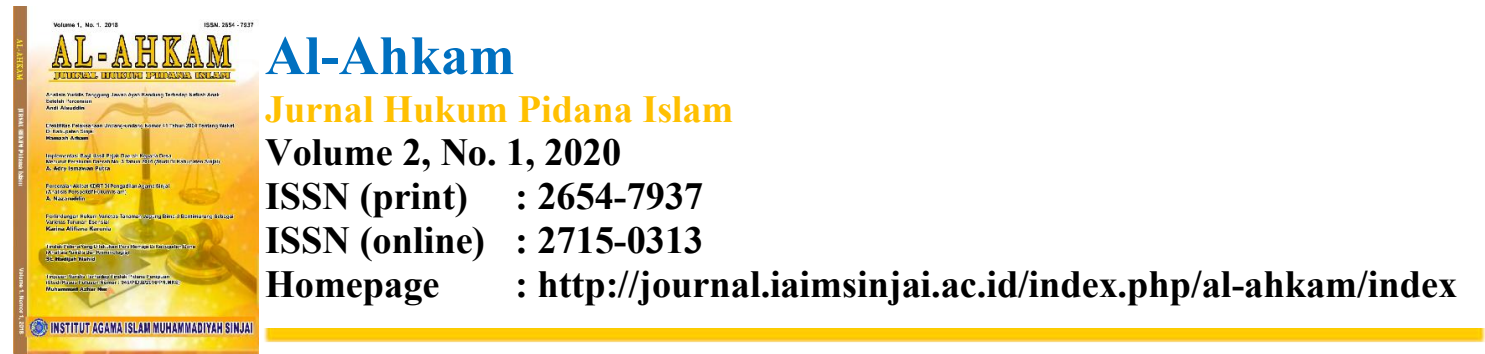

Keywords: Legal Protection, Children, Investigations

\section{Pendahuluan}

Pemerintah wajib hadir dalam perlndungan terhadap anak ketik anak melakukan delik pidana karena anak sebagai insan yang rentan terhadap stigma negatif dianggap perlu untuk dilindungi. Berbagai kebijaksanaan yang di dapat oleh anak ketika melakukan delik telah diatur di dalam Peraturan Perundang Undangan mengenai Perlindungan Anak sebagai suatu payung hukum agar nantinya anak tidak mengalami kesulitan dalam menghadapi persoalan hukum khususnya di Indonesia. Kenakalan anak yang biasa disebut juvenille telah menjadi pokok bahasan sejak Konstitusi Indonesia di sahkan sebagai Dasar Negara Republik Indonesia.

Kenakalan remaja (juvenile) adalah ketika seseorang yang belum memasuki usia dewasa,belum kawin atau masih dalam tahap usia tertentu. Makna dari defenisi tersebut memberikan batasan tentang apa yang dinamakan remaja.. Batas usia tertentu apabila dikaitkan dengan pertanggung- jawaban pidana, memiliki pembatasan umur minimal dan maksimal, yang pembedaannya bergantung dari manakah melihat dan menafsirkannya.

Zakiah Darajat mengatakan bahwa mengenai batas usia anak- anak dan dewasa berdasarkan pada usia remaja adalah bahwa masa usia 9 (sembilan) tahun, antara 13 (tiga belas) tahun sampai 21 (dua puluh satu) tahun sebagai masa remaja merupakan masa peralihan antara masa anak-anak dan masa dewasa, di mana anak-anak mengalami pertumbuhan yang cepat di segala bidang dan mereka bukan lagi anak-anak baik bentuk badan, sikap, cara berpikir dan bertindak tetapi bukan pula orang dewasa. (Abiantoro, 2016:36)

Batas usia ke bawah ialah keadaan usia termuda, di mana pelaku tindak pidana dapat dikenakan hukuman, di setiap negara memiliki pembatasan khusus tentang batasan umur berapa yang dapat dikenakan hukuman sesuai dengan kultur dan budaya di setiap negara karena pada dasarnya pemaknaan mengenai batasan umur disesuaikan dengan kebijakan pemerintah di setiap negara

Sekarang ada kecenderungan untuk menghilangkan batas usia ke bawah, dengan demikian pertanggungjawaban pelaku tindak pidana tidak dipersoalkan apakah ia melanggar norma hukum, dianggap sebagai anak yang memerlukan bantuan. Jadi tindakannya bukan atas nama keadilan namun atas nama kemanusiaan yang menuntut pemberian pertolongan dan bantuan.

Penggolongan juvenile sebagai Batas usia ke atas ialah untuk menentukan siapa yang sampai batas ini diberikan kedudukan sebagai juvenile, sehingga harus diperlakukan secara khusus. Dalam menjalani kehidupannya seorang anak telah mendapatkan perlindungan terhadap hak - hanya yang telah diberikan Undang Undang.

Arif Gosita memberikan pemahaman tentang ruang lingkup dari pelaksanaan hukum perlindungan bagi anak Ruang lingkupnya adalah

1. Perlindungan yang pokok, meliputi antara lain; sandang, pangan, pemukiman, pendidikan dan kesehatan;

2. Meliputi hal-hal yang jasmaniah dan rohaniah;

3. Mengenai pula penggolongan keperluan yang primer dan sekunder yang berakibat pada prioritas pemenuhannya". (Arif Gosita, 1989:5)

Ditinjau secara garis besar maka dapat disebutkan bahwa perlindungan anak dapat dibedakan dalam 2 (dua) pengertian ialah;

a. Perlindungan yang bersifat yuridis, meliputi;

1) bidang hukum publik;

2) bidang hukum keperdataan; 


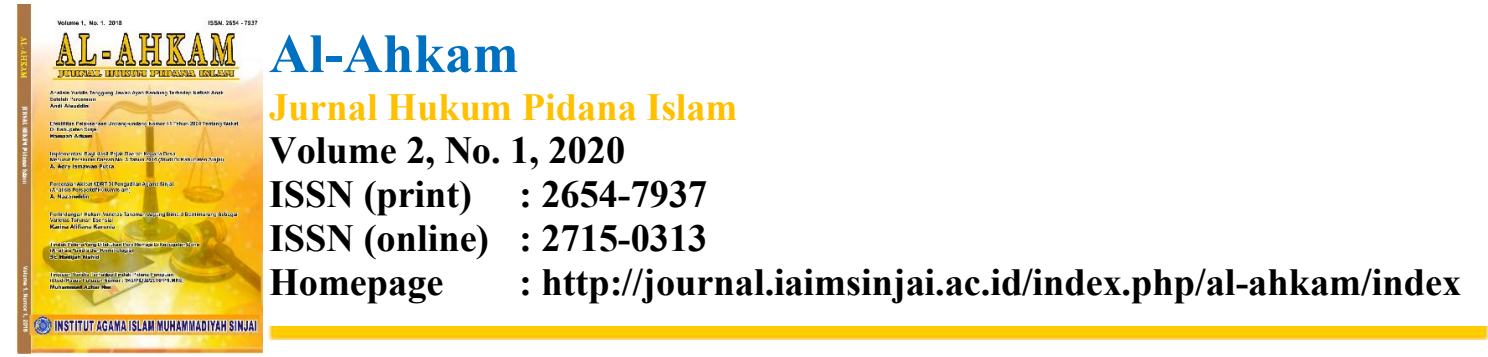

b. Perlindungan yang bersifat non yuridis meliputi;

1) bidang sosial;

2) bidang kesehatan;

3) bidang pendidikan. (Abiantoro, 2016:23-24)

Berkaitan dengan Undang-undang Nomor 23 Tahun 2002, terdapat beberapa tambahan menyangkut Perlindungan Anak yaitu diatur dalam Undang-Undang Nomor 35 Tahun 2014 yang telah diubah menjadi Undang - Undang Nomor 17 Tahun 2016 yang mana diatur dalam beberapa pasal yakni Pasal 6, Pasal 9 ayat (1) (1a) (2), Pasal 12, Pasal 14 ayat (1) (2), dan Pasal 15.

Mengenai hak anak juga diatur dalam Undang Undang Sistem Peradilan Pidana Anak. Dalam Undang Undang ini anak wajib mendapatkan perlindungan ketika terlibat dalam tindak pidana. Pasal 3 menyebutkan bahwa

Dalam hal proses peradilan pidana, anak berhak:

1) Diperlakukan secara manusiawi dengan memperhatikan kebutuhan sesuai dengan umurnya

2) Dipisahkan dari orang dewasa

3) Memperoleh bantuan hukum dan bantuan lain secara efektif

4) Melakukan kegiatan rekreasional

5) Bebas dari penyiksaan, penghukuman atau perlakuan lain yang kejam, tidak manusiawi, serta merendahkan derajat dan martabatnya

6) Tidak dijatuhi pidana mati atau pidana seumur hidup

7) Tidak ditangkap, ditahan, atau dipenjara, kecuali sebagai upaya terakhir dan dalam waktu yang paling singkat

8) Memperoleh keadilan di muka pengadilan anak yang objektif, tidak memihak, dan dalam sidang yang tertutup untuk umum

9) Tidak dipublikasikan identitasnya

10) Memperoleh pendampingan orang tua/wali dan orang yang dipercaya oleh anak

11) Memperoleh advokasi sosial

12) Memperoleh kehidupan pribadi

13) Memperoleh aksesibilitas, terutama bagi anak cacat

14) Memperoleh pendidikan

15) Memperoleh pelayananan kesehatan

16) Memperoleh hak lain sesuai dengan ketentuan peraturan perundangundangan.

Perlindungan terhadap anak nakal yang telah menjadi tersangka telah diatur sedemikian rupa sehingga anak berhak mendapatkan perlindungan sejak tingkatan Penyidikan sampai dengan Pengadilan.

Pada hakikatnya, istilah tersangka merupakan terminologi dalam Kitab UndangUndang Hukum Acara Pidana yang dibedakan dengan terdakwa. Berbeda halnya dalam sistem hukum Belanda yang termaktub dalam Wetboek van Strafvordering, ternyata istilah tersangka atau Beklaagde dan terdakwa atau erdachte tidak dibedakan pengertiannya dan dipergunaan dengan satu istilah saja yaitu Verdachte. (Lilik Mulyadi, 2007 : 49).

Proses penyidikan terhadap anak tetaplah harus mengikuti rambu rambu yang telah ditentukan oleh Undang Undang Perlindungan Anak agar tidak terjadi intimidasi terhadap anak dalam proses penyidikan tindak pidana.

Berdasarkan paparan singkat latar belakang maka peneliti ingin melakukan penelitian dengan judul Perlindungan Hukum Terhadap Tersangka dalam Proses Penyidikan di Kepolisian Resor Pohuwato 


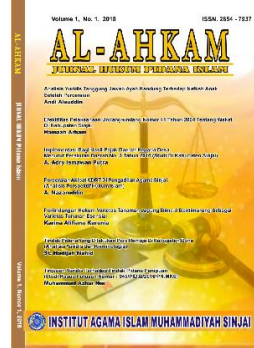

\section{Metode Penelitian}

\section{Jenis dan Sifat Penelitian}

Dalam penelitian ini penulis menggunakan penelitian hukum empiris yaitu suatu penelitian yang menggunakan data primer untuk menjawab persoalan yang diteliti.

\section{Objek Penelitian}

Objek di dalam penelitian ini adalah mengenai perlindungan anak dalam tingkat penyidikan di Polres Pohuwato.

\section{Lokasi Penelitian}

Penelitian ini dilaksanakan dari bulan Juni 2019 sampai dengan Januari 2020 di Polres Pohuwato.karena lokasi tersebut relevan dengan persoalan yang penulis teliti

\section{Jenis dan Sumber Data}

Jenis data yang digunakan dalam penelitian ini yaitu:

1. Data primer

Pengumpulan data primer dilakukan dengan cara wawancara (interview) dengan narasumber berdasarkan pokok-pokok pertanyaan yang berkaitan langsung dengan permasalahan dalam penelitian ini.

2. Data sekunder

Sumber data sekunder merupakan sumber data yang memberikan keterangan pendukung bagi sumber data primer, bahan hukum primer, sekunder, dan tersier.

\section{Teknik Pengumpulan Data}

Dalam pengumpulan data yaitu penulis meminta data yang diperlukan dari Polres Pohuwato dan mewawancarai Penyidik Polres Pohuwato. Selain itu penulis juga mengumpulkan peraturan perundang-undangan, literatur, dokumen serta website yang berkaitan dengan masalah yang diteliti. bahan-bahan kepustakaan yang relevan dengan penelitian yang penulis teliti baik dari buku maupun media.

\section{Analisis Data}

Data yang terkumpul dalam penelitian ini diseleksi menurut tingkatan validitasnya dan selanjutnya di analisis. Untuk memudahkan menganalisis data, digunakan pendekatan kualitatif. Analisis secara kualitatif ditujukan untuk menganalisis data-data yang sukar untuk dikualitatifkan seperti bahan pustaka, dokumen-dokumen dan lain-lain

\section{Hasil dan Pembahasan}

\section{Perlindungan Hukum Terhadap Anak Dalam Tahap Penyidikan}

Lili Rasjidi dan I.B. Wyasa Putra (1993:123) mengemukakan bahwa hukum dapat difungsikan tidak hanya mewujudkan kepastian, tetapi juga jaminan perlindungan dan keseimbangan yang sifatnya tidak sekedar adaptif dan fleksibel, namun juga prediktif dan antisipatif.

Menurut Philipus M. Hadjon (1987:2) perlindungan hukum adalah Suatu kondisi subyektif yang menyatakan hadirnya keharusan pada diri sejumlah subyek untuk segera memperoleh sejumlah sumberdaya guna kelangsungan eksistensi subyek hukum yang dijamin dan dilindungi oleh hukum, agar kekuatannya secara terorganisasi dalam proses 


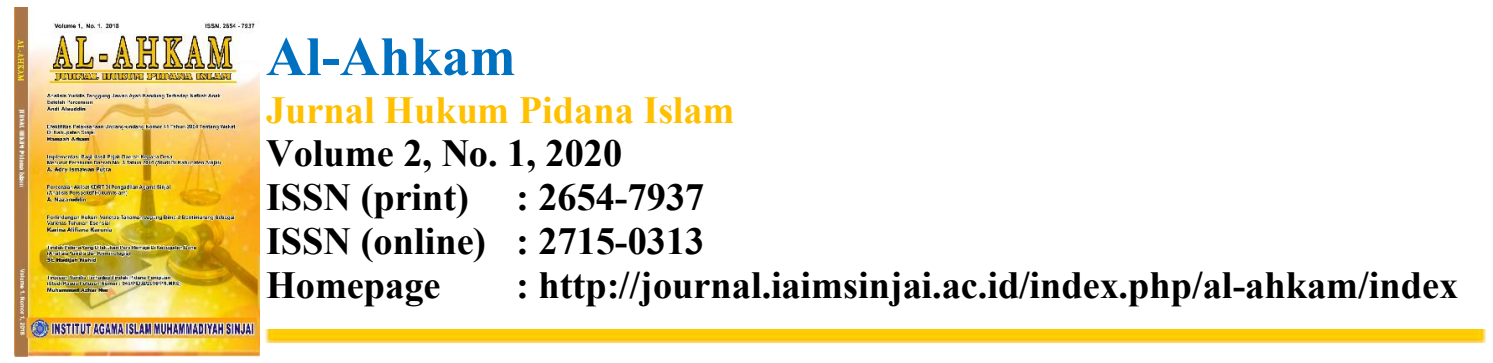

pengambilan keputusan politik maupun ekonomi, khususnya pada distribusi sumber daya, baik pada peringkat individu maupun strukturalDalam menjalani kehidupannya seorang anak telah mendapatkan perlindungan terhadap hak - hanya yang telah diberikan Undang Undang. Berkaitan dengan Undang-undang Nomor 23 Tahun 2002, terdapat beberapa tambahan menyangkut Perlindungan Anak yaitu diatur dalam Undang-Undang Nomor 35 Tahun 2014 yang telah diubah menjadi Undang - Undang Nomor 17 Tahun 2016 yaitu:

a) Melalui bimbingan dari Orang Tua atau Wali Anak memiliki hak untuk berpikir, berekspresi sesuai dengan tingkat kecerdasan dan usianya serta beribadah menurut agamanya, , dan (Pasal 6).

b) Anak memiliki hak untuk memperoleh pendidikan dan pengajaran untuk mengembangkan pribadinya serta tingkat kecerdasannya yang sesuai dengan minat dan bakat (Pasal 9 ayat (1)).

c) Anak memiliki hak untuk mendapatkan perlindungan di dalam satuan pendidikan jangan sampai anak tersebut menjadi korban kejahatan dalam bentuk seksual dan kekerasan. Kejahatan itu kemungkinan dapat dilakukan pihak yang terlibat dalam satuan pendidikan seperti sesama peserta didik, tenaga kependidikan, pendidikan, dan/atau pihak lain (Pasal 9 ayat (1a)).

d) Anak Penyandang Disabilitas memiliki hak untuk memperoleh pendidikan luar biasa dan anak yang memiliki keunggulan memiliki hak untuk mendapatkan pendidikan khusus (Pasal 9 ayat (2)).

e) Anak Penyandang Disabilitas memiliki hak untuk memperoleh pemeliharaan taraf kesejahteraan sosial, bantuan sosial, dan rehabilitasi (Pasal 12).

f) Anak memiliki hak untuk mendapatkan pengasuhan dari Orang Tuanya sendiri, namun apabila terdapat alasan dan/atau aturan hukum yang sah menunjukkan bahwa dilakukan pemisahan dengan orang tuanya dengan alasan demi kepentingan yang terbaik bagi Anak dan merupakan pertimbangan terakhir (Pasal 14 ayat (1)).

g) Anak memiliki hak untuk berhubungan pribadi secara tetap dan bertemu langsung dengan kedua orang tuanya, mendapatkan pendidikan pemeliharaan, pengasuhan, dan perlindungan untuk proses tumbuh kembang dari kedua orang tuanya sesuai dengan kemampuan, minat dan bakatnya, dan kedua Orang Tuanya memberikan biaya hidup, dan memperoleh Hak Anak lainnya, ketika terjadi pemisahan anak (Pasal 14 ayat (2)).

h) Hak untuk memperoleh perlindungan dari penyalahgunaan dalam kegiatan politik,pelibatan dalam sengketa bersenjata, pelibatan dalam kerusuhan sosial, pelibatan Dalam peristiwa yang mengandung unsur kekerasan, pelibatan dalam peperangan, dan kejahatan seksual (Pasal 15).

Mengenai hak anak juga diatur dalam Undang Undang Sistem Peradilan Pidana Anak. Dalam Undang Undang ini anak wajib mendapatkan perlindungan ketika terlibat dalam tindak pidana. Pasal 3 menyebutkan bahwa dalam hal proses peradilan pidana, anak berhak:

a. Diperlakukan secara manusiawi dengan memperhatikan kebutuhan sesuai dengan umurnya

b. Dipisahkan dari orang dewasa

c. Memperoleh bantuan hukum dan bantuan lain secara efektif

d. Melakukan kegiatan rekreasional

e. Bebas dari penyiksaan, penghukuman atau perlakuan lain yang kejam, tidak manusiawi, serta merendahkan derajat dan martabatnya

f. Tidak dijatuhi pidana mati atau pidana seumur hidup 


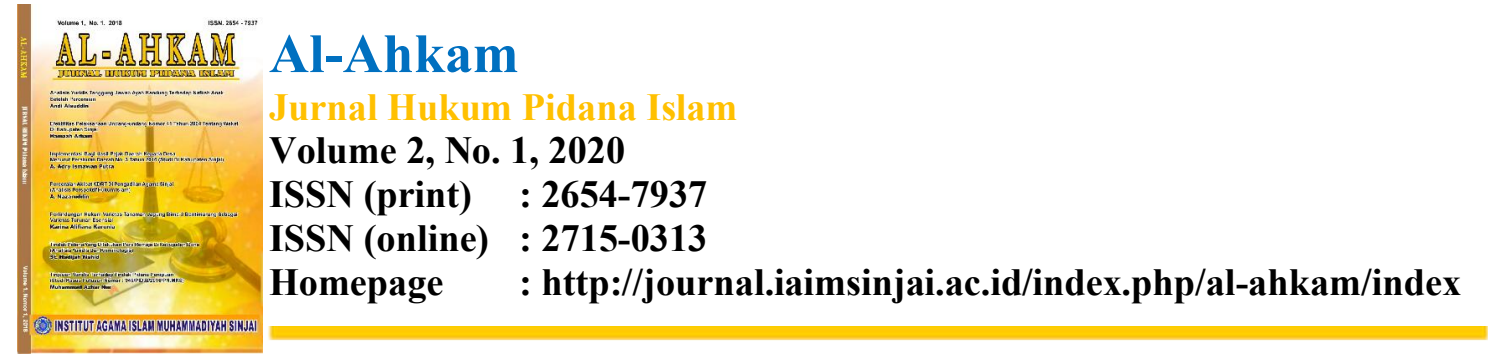

g. Tidak ditangkap, ditahan, atau dipenjara, kecuali sebagai upaya terakhir dan dalam waktu yang paling singkat

h. Memperoleh keadilan di muka pengadilan anak yang objektif, tidak memihak, dan dalam sidang yang tertutup untuk umum

i. Tidak dipublikasikan identitasnya

j. Memperoleh pendampingan orang tua/wali dan orang yang dipercaya oleh anak

k. Memperoleh advokasi sosial

1. Memperoleh kehidupan pribadi

m. Memperoleh aksesibilitas, terutama bagi anak cacat

n. Memperoleh pendidikan

o. Memperoleh pelayananan kesehatan

p. Memperoleh hak lain sesuai dengan ketentuan peraturan perundangundangan.

Barda Nawawi Arief menyatakan bahwa ruang lingkup masalah perlindungan anak cukup luas, terlihat dari cukup banyaknya dokumen/instrumen internasional yang berkaitan dengan masalah anak, dari berbagai dokumen dan pertemuan internasional terlihat bahwa kebutuhan terhadap perlunya perlindungan hukum bagi anak dapat mencakup berbagai bidang/aspek, antara lain;

a. perlindungan terhadap hak-hak asasi dan kebebasan anak;

b. perlindungan anak dalam proses peradilan;

c. perlindungan kesejahteraan anak (dalam lingkungan keluarga, pendidikan dan lingkungan sosial);

d. perlindungan anak dalam masalah penahanan dan perampasan kemerdekaan;

e. perlindungan anak dari segala bentuk eksploitasi (perbudakan, per- dagangan anak, pelacuran, pomografi, perdagangan/penyalahgunaan obat-obatan, memperalat anak dalam melakukan kejahatan dsb);

f. perlindungan terhadap street children;

g. perlindungan anak dari akibat peperangan/konflik bersenjata;

$\mathrm{h}$. perlindungan the children in around conflict". (Barda Nawawi, 1996:69)

Pelaksanaan penyidikan terhaddap orang dewasa dan anak sangatlah berbeda namun pengertian penyidikan tidaklah berubah. Menurut R Soesilo (1996:17) Istilah penyidikan sinonim dengan pengusutan, merupakan terjemahan dari istilah Belanda Osporing atau dalam bahasa Inggrisnya Investigation. Penyidik berasal dari kata sidik, yang berarti terang dan bekas. Maksudnya penyidikan membuat terang atau jelas dan penyidikan berarti mencari bekas - bekas, dalam hal ini bekas - bekas kejahatan. Bertolak dari kedua kata terang dan bekas arti kata sidik itu, maka penyidikan artinya membuat terang kejahatan.

Anak yang melakukan tindak pidana tentunya akan diperlakukan sangat berbeda dengan orang dewasa. Hal ini karena anak memiliki sistem acara tersendiri dalam UU Sistem Peradilan Pidana Anak selain itu hak haknya sebagai anak haruslah selalu dilindungi demi terwujudnya perlindungan anak. Dalam penelitian yang dilaksanakan di Polres Pohuwato khususnya pada Unit Pelayanan Perempuan dan Anak, penulis ingin mengetahui apakah selama ini Pihak Penyidik Anak telah melaksanakan tugasnya dalam melindungi hak-hak anak.

Berdasarkan data yang peneliti dapatkan bahwa telah terjadi 29 kasus yanag dilakukan oleh anak yaitu :

Tabel 1. Jumlah Tersangka Anak dari tahun 2018-2020 di Polres Pohuwato 


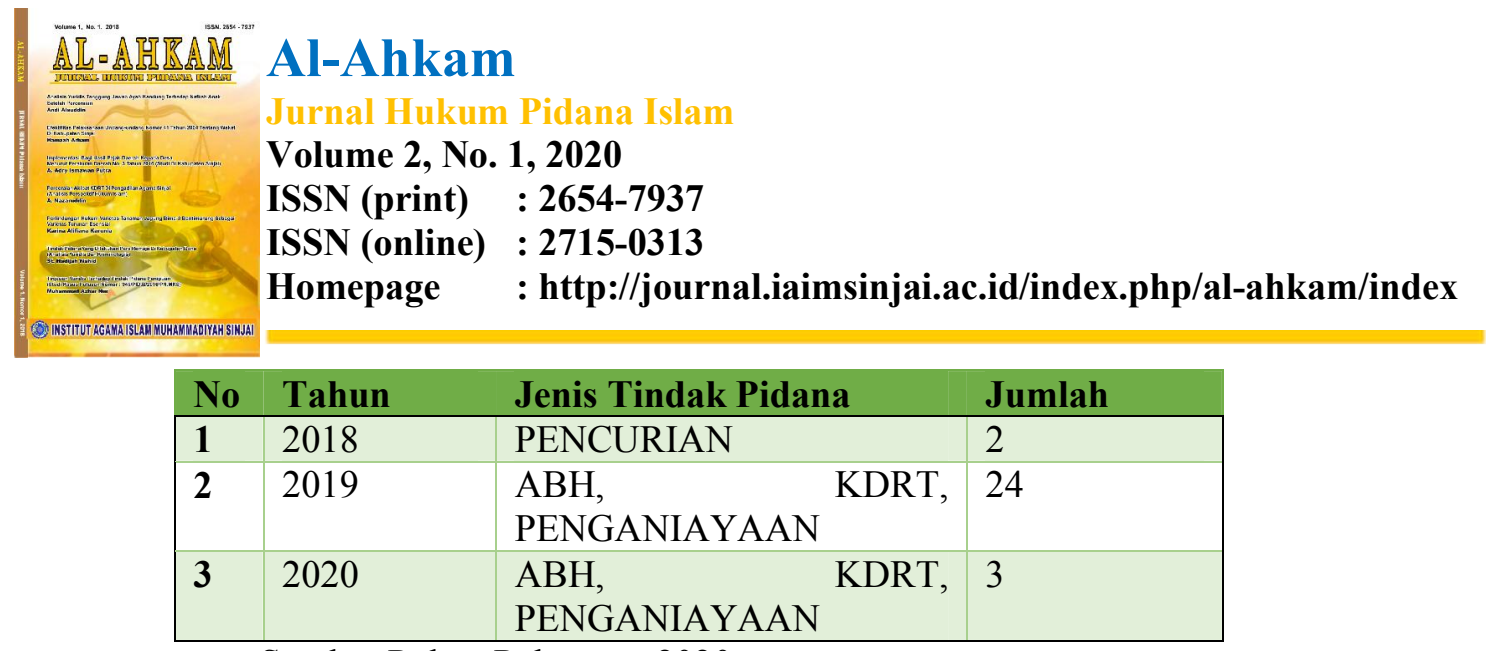

Sumber Polres Pohuwato 2020

Berdasarkan data diatas dapat diketahui bahwa pada tahun 2018 terdapat 2 kasus anak sebagai pelaku tindak pidana dengan kasus pencurian, pada tahun 2019 terdapat 24 kasus terdiri dari kasus kasus ABH, KDRT dan Penganiayaan dan pada tahun 2020 terdapat 3 kasus ABH, KDRT, Penganiayaan.

Pada saat penulis mengadakan penelitian pada Unit PPA Polres Pohuwato ada beberapa hal yang dilakukan oleh penyidik pada saat melakukan pemeriksaan terhadap anak sebagai tersangka :

1. Dalam pemeriksaan terhadap tersangka anak penyidik akan memberikan penjelasan mengenai hak-hak yang dimiliki anak sesuai Undang undang dengan memakai kalimat maupun bahasa sesuai dengan pemahaman dan umur yang dimiliki oleh anak tersebut.

2. Dalam pelaksanaan pemeriksaan terhadap anak, penyidik wajib memanggi pendamping anak dan dapat saja anak memilih orang tertentu yang dipercayai/orang dewasa (kehadiran orang tua harus diutamakan) serta pendampingan dari penasehat hukum, BAPAS, P2TP2A, psikolog atau pembimbing lainnya untuk terlibat pada saat pemeriksaan.

3. Ketika anak tidak ingin didampingi penasehat hukum harus dibuatkan berita acaranya.

4. Kedua atau salah satu Orang tua yang mendampingi harus pula diberikan pemahaman dan penjelasan tentang hak - hak yang dimiliki oleh anaknya pada saat pemeriksaan.

5. Penyidik memberikan waktu kepada anak dan orang tuanya untuk berkomunikasi secara pribadi.

6. Segala Keterangan yang diberikan oleh anak, yang dapat dijadikan sebagai bukti dalam BAP hanyalah ketika anak tersebut mendapatkan pendampingan dari berbagai pihak terkait. Tanpa itu maka keterangan tersebut tidak sah.

Berdasarkan wawancara penulis dengan Briptu Jellyta Carolin Gress,S.H (wawancara tanggal 10 Januari 2020bahwa Dalam proses penyidikan anak sebagai pelaku dilakukan pemulihan kembali, seperti anak mendapat pendampingan dari lembaga2 terkait. Pendampingan dari BAPAS, Dinas Sosial, P2TP2A, LBH, Dinas Pendidikan dan Dinas Kesehatan untuk memulihkan anak sebagai pelaku. Tersangka Anak Wajib mendapat Perlindungan dari lembaga terkait Agar tidak cacat Fisik,Mental,Pada saat berhadapan dengan Hukum.

Di samping itu Undang-Undang Perlindungan Anak Memberikan Jaminan Terhadap Anak Agar dapat Hidup, Tumbuh Jadi Dewasa, Berkembang Dan Berpartisipasi Secara Optimal Dan Terhindar Dari Kekerasan Dan Diskriminasi Demi Terwujudnya Anak Indonesia Yang Berkualitas Dan Berahlak Mulia.

Selanjutnya Menurut Bapak Bripka Haman Kunding (wawancara Jajnuari 2020) selaku Penyidik yang pernah menangani kasus anak mengatakan bahwa setiap anak yang pernah diperiksa sebagai tersangka selalu mendapatkan bantuan hukum dan pendampingan lembaga terkait. Terkadang pada pemeriksaan yang sifatnya mendesak yang bersifat urgent 


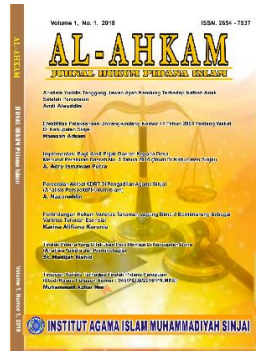

Al-Ahkam

Jurnal Hukum Pidana Islam

Volume 2, No. 1, 2020

ISSN (print) : 2654-7937

ISSN (online) : 2715-0313

Homepage : http://journal.iaimsinjai.ac.id/index.php/al-ahkam/index

untuk pemeriksaan pertama belum dilibatkan Penasehat Hukum ataupun Bapas karena BAPAS hanya terdapat di Provinsi Gorontalo tetapi untuk pemeriksaan berikutnya Penasehat Hukum dan beberapa lembaga lainnya tetap dilibatkan. Perlu juga ditegaskan bahwa pada pemeriksaan pertama tersangka anak biasanya menolak untuk dihadirkan Penasehat Hukum sehingga harus dibuatkan berita acaranya tetapi pada pemeriksaan keduanya penyidik akan menghadirkan penasehat hukum guna perlindungan hak tersangka anak.

Pada tahap pemeriksaan pada kepolisian setiap kasus pasti akan dilakukan penangkapan dan penahanan tidak terkecuali pada kasus anak. Dalam setiap kasus anak tidak selalu haris dilakukan penangkapan dan penahanan

Dalam KUHAP Pasal 1 (20) memberikan pemahaman tentang penagkapan yakni:

Penangkapan adalah suatu tindakan penyidik berupa pengekangan sementara waktu kebebasan tersangka atau terdakwa apabila terdapat cukup bukti guna kepentingan penyidikan atau penuntutan dan atau peradilan dalam hal serta menurut cara yang diatur dalam undang-undang ini.

Apabila penangkapan telah dilakukan maka selanjutnya akan dilakukan tindakan penahanan terhadap anak sesuai dengan amanat Pasal 1 (21) KUHAP yang mengatur bahwa :

Penahanan adalah penempatan tersangka atau terdakwa di tempat tertentu oleh penyidik, atau penuntut umum atau hakim dengan penetapannya, dalam hal serta menurut cara yang diatur dalam undang-undang ini.

Penerapan Asas Praduga tak bersalah tetap dipegang oleh penyidik tanpa membedakan apakah yang ditangkap adalah anak atau dewasa. Dalam melakukan penangkapan diperhatikan hak - hak anak sebagai tersangka, anak sebagai subjek hukum yang istimewa memiliki kekhususan untuk mengesampingkan berbagai upaya paksa maupun berbagai tindakan paksa dalam proses pelaksanaan penyidikan. Ketika terjadi pertemuan awal antara penyidik dengan anak, kekerasan psikis ataupun fisik musti dihindarkan sehingga anak mendapatkan berbagai haknya sesuai dengan aturan perundang -undangan yang berlaku dalam rangka perlindungan terhadap hak-hak anak yang meliputi

1. Dalam pelaksanaan upaya penangkapan keluarga anak yang disangka sebagai pelaku tindak pidana wajib mendapatkan pemberitahuan terlebih dahulu baik melalui lisan ataupun tulisan sehingga pelaksanaan penangkapan tetap menjamin hak anak.

2. Ketika dilaksakanakan penangkapan terhadap anak yang disangka melakukan tindak pidana, penyidik/pihak kepolisian dilarang untuk memakai atau menggunakan senjata ataupun alat upaya paksa atau wewenang paksa.

3. Pemberian bantuan hukum gratis atau secara Cuma-Cuma wajib didapatkan anak yang disangka melakukan tindak pidana pada saat anak ditangkap dan ditahan baik dalam proses penyidikan maupun penuntutan sehingga penasehat hukum tersebut nantinya akan menjadi penasehat yang hadir atau mendampingi anak dalam proses pemeriksaan di pengadilan.

4. Pemeriksaan terhadap anak yang berstatus tersangka harus dilaksanakan segera meungkin tanpa adanya penundaan.

5. Anak tetap akan mendapatkan rehabilitasi ataupun ganti kerugian apabila terjadi kesalahan.

Tabel 2.

Jumlah Penangkapan dan penahanan terhadap anak di Polres Pohuwato 


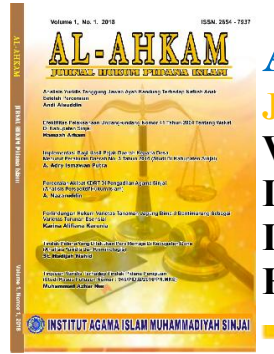

\begin{tabular}{|l|l|l|l|l|} 
No & \multicolumn{1}{|c|}{ Tahun } & \multicolumn{1}{c|}{$\begin{array}{c}\text { Jenis Tindak } \\
\text { Pidana }\end{array}$} & Penangkapan & \multicolumn{1}{c|}{ Penahanan } \\
\hline $\mathbf{1}$ & 2018 & PENCURIAN & 1 & NIHIL \\
\hline $\mathbf{2}$ & 2019 & $\begin{array}{l}\text { ABH, KDRT, } \\
\text { PENGANIAYAAN }\end{array}$ & 1 & 1 \\
\hline $\mathbf{3}$ & Januari 2020 & $\begin{array}{l}\text { ABH, KDRT, } \\
\text { PENGANIAYAAN }\end{array}$ & 1 & 1 \\
\hline
\end{tabular}

Sumber Polres Pohuwato 2020

Berdasarkan data diatas dapat diketahui bahwa pada tahun 2018 dari 2 kasus dilakukan penngkapan pada 1 kasus namun tidak dilakukan penahanan, pada tahun 2019 dari 24 kasus dilakukan penangkapan pada 1 kasus dan dilakukan penahanan 1 Kasus dan pada 2020 dari 3 kasus yang terjadi dilakukan penangkapan 1 kasus dan penahanan 1 kasus.

Menurut Ibu Bripda Trianti bahwa mengenai penangkapan dan penahanan terhadap anak di tingkat Penyidikan Polres Pohuwato jarang dan bahkan sama sekali tidak dilakukan, namun apabila penangkapan dan penahan dilakukan tindakan tertentu yang diambil Alih adalah menempatkan anak di lembaga pembinaan khusus, namun apabila lembaga pembinaan khusus tidak ada khususnya untuk wilayah Pohuwato, penyidik akan mengarahkan anak sebagai pelaku di lembaga penyelenggaraan sosial di pohuwato yang biasanya di tempatkan di Masjid Baitullrahim.

Tabel 3. Data Penyelesaian Kasus Anak Pada Polres Pohuwato

\begin{tabular}{|l|l|l|l|l|l|}
\hline No & Tahun & Jenis Tindak Pidana & P21 & ADR & DIVERSI \\
\hline $\mathbf{1}$ & 2018 & PENCURIA KIHIL & NIHIL & 2 \\
\hline $\mathbf{2}$ & 2019 & $\begin{array}{l}\text { ABH, KDT, } \\
\text { PENGANIAYAAN }\end{array}$ & 2 & 14 & 1 \\
\hline $\mathbf{3}$ & $2020 \quad \begin{array}{l}\text { ABH, KDRT, NIHIL } \\
\text { PENGANIAYAAN }\end{array}$ & 3 & NIHIL \\
\hline
\end{tabular}

Sumber Polres Pohuwato 2020

Dari data diatas dapat diketahui bahwa kedua kasus pada tahun 2018 dilaksanakan diversi, pada tahun 2019 dari 24 kasus terdapat 2 kasus yang P21, 14 kasus dilakukan ADR dan 1 Kasus dilakukan diversi dan pada tahun 2020 dari 3 kasus kesemuanya dilaksanakan penyelesaian melalui ADR

Dalam penyelesaian kasus anak penyidik polres pohuwato unit Perlindungan Perempuan dan Anak (PPA) mengupayakan diversi. Berdasarkan penelitian penulis di Polres Pohuwato dalam melaksanakan diversi melalui mediasi penal selalu berpatokan pada Undang - Undang No 11 Tahun 2012 tentang SPPA. pelaksanaan diversi harus sesai dengan amanat Pasal 7 (2) UU SPPA yakni diversi dilaksanakan dalam hal tindak pidana yang dilakukan: diancam dengan pidana penjara di bawah 7 (tujuh) tahun dan bukan merupakan pengulangan tindak pidana

Pelaksanaan ADR dilakukan melalui diskresi kepolisian. contoh-contoh tindak pidana yang dilakukan oleh anak yang dapat diselesaikan dengan diskresi pada tahap penyidik sebagai berikut; 


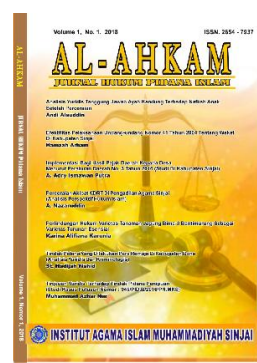

Volume 2, No. 1, 2020

ISSN (print) : 2654-7937

ISSN (online) : 2715-0313

Homepage : http://journal.iaimsinjai.ac.id/index.php/al-ahkam/index

1. Tindak pidana yang dapat dilakukan diskresi:

a. perusakan barang secara terbuka atas barang pribadi (vandalisme);

b. pembakaran yang membahayakan barang;

c. pencurian tanpa membobol rumah;

d. penggelapan barang;

e. percobaan melakukan tindak pidana ringan;

f. penadahan;

g. pelanggaran lalu lintas;

h. tersangkut urusan obat-obat yang dilarang;

i. pelanggaran yang tidak menyangkut kepentingan umum;

j. pelecehan seksual;

k. memiliki senjata illegal.

2. Kenakalan anak:
a. pencorengan sarana publik;
b. berandalan;
c. menyulut petasan yang membahayakan lingkungan umum;
d. melarikan diri dari rumah;
e. tawuran

selain dari pelaksanaan ADR juga dilaksanakan diversi. Berdasarkan hasil penelitian penulis di Unit PPA Polres Pohuwato, penanganan anak yang berhadapan dengan hukum dibedakan penanganannya bagi yang berumur di bawah 12 tahun dan di atas 12 tahun. Dalam penanganannya untuk saat ini dapat dilihat dalam bagan berikut :

Bagan 1. Alur penanganan diversi melalui mediasi penal bila ABH berusia $12-18$ tahun bila terdapat korban

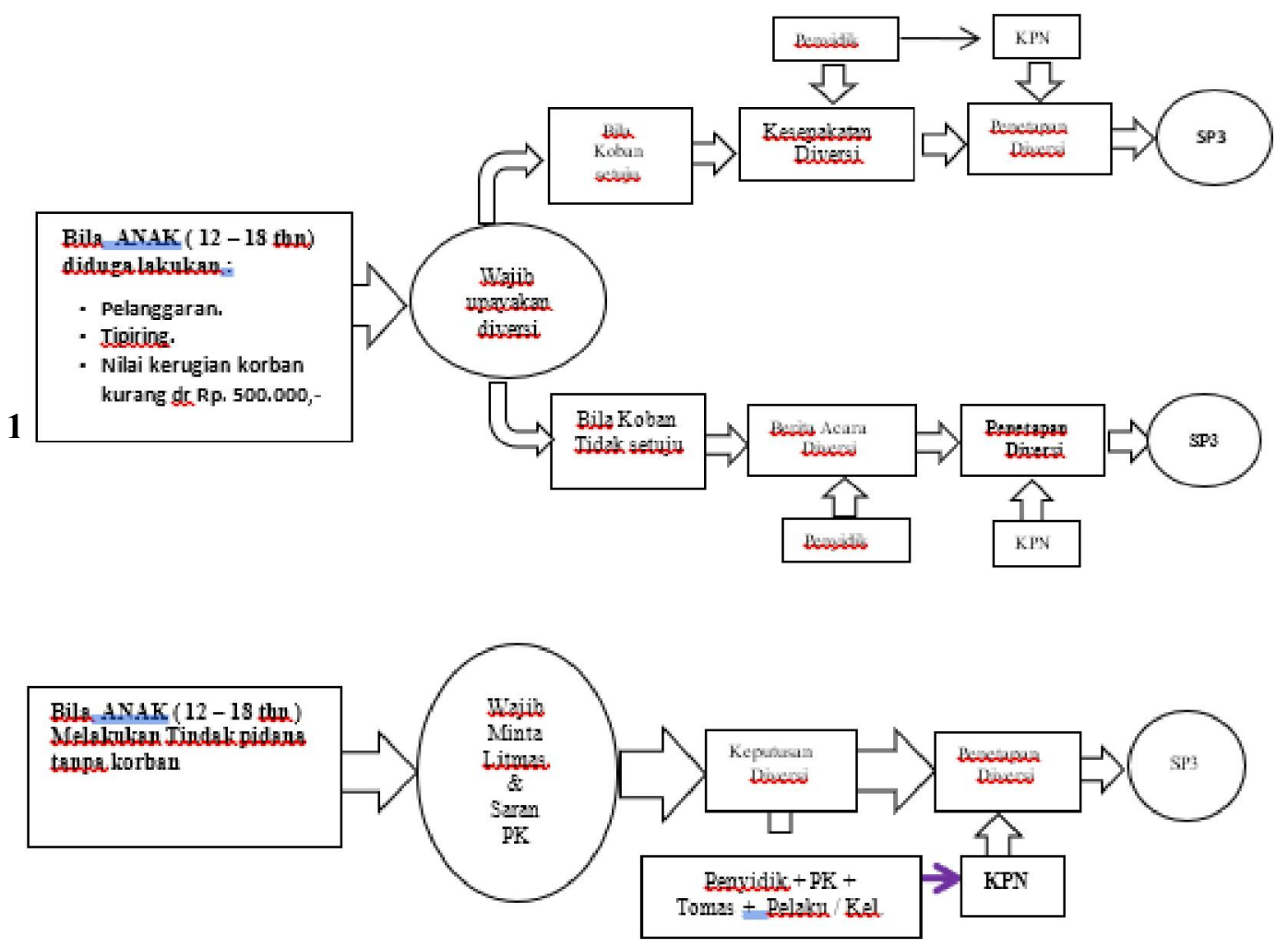




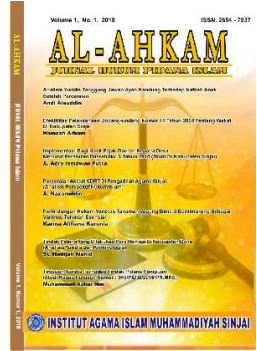

Volume 2, No. 1, 2020

ISSN (print) : 2654-7937

ISSN (online) : 2715-0313

Homepage : http://journal.iaimsinjai.ac.id/index.php/al-ahkam/index Pidana:

Berdasarkan bagan diatas bila Anak usia 12 - 18 thn diduga melakukan Tindak

a. Dalam melakukan penyidikan terhadap Anak, penyidik wajib meminta pertimbangan / saran tertulis dari petugas Pembimbing Kemasyarakatan / PK / Bapas setelah tindak pidana dilaporkan / diadukan (vide pasal 27 (1) ).

b. Hasil Penelitian Kemasyarakatan wajib diserahkan oleh Bapas kepada penyidik dalam waktu paling lama 3 x 24 jam setelah permintaan penyidik diterima ( vide pasal 28).

c. Penyidik wajib mulai mengupayakan Diversi dalam waktu paling lama 7 (tujuh) hari setelah penyidikan dimulai ( vide pasal 29 (1) ).

d. Proses Diversi tersebut dilaksanakan paling lama 30 hari setelah dimulainya diversi ( vide pasal 29 (2)) .

Dalam pelaksanaan diversi yang dilakukan penyidik tetaplah mengikuti arahan dari Undang - Undang SPPA Pasal 8 (3):

a. kepentingan korban;

b. kesejahteraan dan tanggung jawab Anak;

c. penghindaran stigma negatif;

d. penghindaran pembalasan;

e. keharmonisan masyarakat; dan

f. kepatutan, kesusilaan, dan ketertiban umum.

Penetapan Diversi harus sudah dikeluarkan oleh Pengadilan Negeri paling lama 3 hari terhitung sejak diterimanya Kesepakatan Diversi.(pasal 13 (3) ). Penyidik menetapkan Penghentian Penyidikan ( SP3 ). Uraian tersbut dapat dilihat dalam bagan sebagai berikut

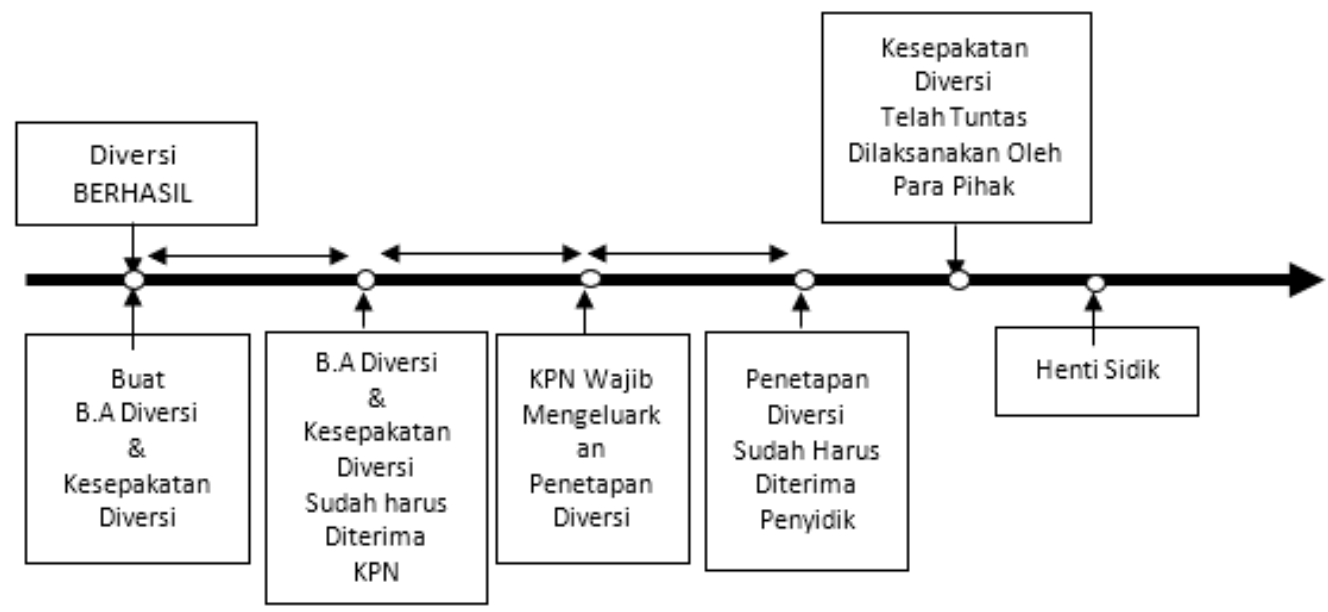

Pada dasarnya diversi mempunyai relevansi dengan tujuan pemidanaan anak. Relevansi diversi dengan tujuan pemidanaan anak, nampak dalam hal-hal sebaga berikut:

1. Diversi sebagai proses pengalihan dari proses yustisial menuju ke proses non yustisial, bertujuan menghindarkan anak dari penerapan hukum pidana yang seringkali menimbulkan pengalaman yang pahit berupa stigmatisasi berkepanjangan dehumanisasi, dan menghindarkan anak dari kemungkinan terjadinya prisionisasi yang menjadi sarana transfer kejahatan terhadap anak. 


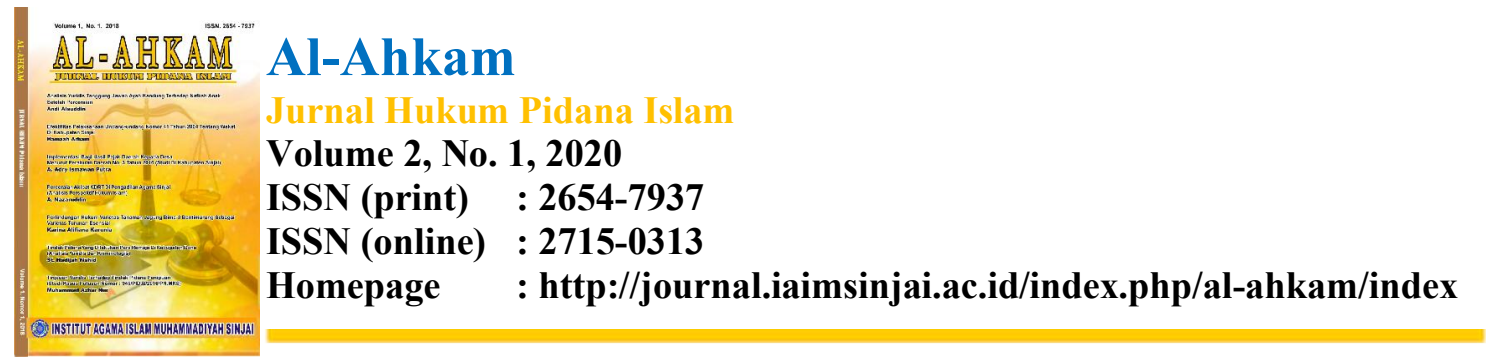

2. Perampasan kemerdekaan terhadap anak, baik dalam bentuk pidana penjara maupun dalam bentuk perampasan yang lain melalui mekanisme peradilan pidana, memberi pengalaman yang traumatis terhadap anak, sehingga anak terganggu perkembangan dan pertumbuhan jiwanya. Pengalaman pahit bersentuhan dengan dunia peradilan akan menjadi bayang- bayang gelap kehidupan anak yang tidak mudah dilupakan

3. Dengan diversi tersebut maka anak terhindar dari penerapan hukum pidana yang dalam banyak teori telah didalilkan sebagai salah satu faktor kriminogen, berarti juga menghin- darkan anak dari kemungkinan menjadi jahat kembali (residivis), menghindarkan masyarakat dari kemungkinan menjadi korban akibat kejahatan.

4. Dengan diversi akan memberikan 2 (dua) keuntungan sekan gus terhadap individu anak; pertama, anak tetap dapa berkomunikasi dengan lingkungannya, sehingga tida perlu beradaptasi sosial pasca terjadinya kejahatan; kedua anak terhindar dari dampak negatif prisonisasi yan seringkali merupakan sarana transfer kejahatan.

Dengan adanya diversi dan ADR maka kasus tersebut akan dihentikan penyidikannya. alasan penghentian penyidikan adalah

1. Delik aduan. Terangka anak melakukan tindak pidana yang termasuk delik aduan sehingga memungkinkan pengadu dapat meencabut aduannya.

2. Orang tua masih dapat membina anaknya yang telah melakukan tindak pidana.

3. Terjadinya perdamaian antara para pihak

\section{Kendala dalam Perlindungan Terhadap Anak Pada Proses Penyidikan Di Polres Pohuwato}

Lili Rasjidi dan I.B. Wyasa Putra (1993:123) mengemukakan bahwa hukum dapat difungsikan tidak hanya mewujudkan kepastian, tetapi juga jaminan perlindungan dan keseimbangan yang sifatnya tidak sekedar adaptif dan fleksibel, namun juga prediktif dan antisipatif.

Berdasarkan penelitian penulis di Polres Pohuwato dan berdasarkan pengalaman para penyidik dalam membuat BAP bahwa Faktor penyebab anak melakukan tidak pidana di kabupaten Pohuwato disebabkan beberapa hal yakni :

- Ekonomi

faktor ekonomi keluarga anak dapat memicu kenakalan pada anak. Anak tersebut terkadang memiliki keinginan untuk memiliki sesuatu yakni barang - barang tertentu. Motivasi tersebut dapat menyebabkan anak melakukan tindak pidana.

- $\quad$ Lingkungan keluarga (tidak mendapat asuhan/didikan yang baik)

Faktor keluarga yang dapat menyebabkan timbulnya kenakalan anak yang berujung pada tindak pidana adalah dapat berupa keluarga yang tidak normal (broken home) dan keadaan jumlah anggota keluarga yang kurang menguntungkan. Menurut Ny. Moelyatno, broken home seperti yang memang menjadi pendapat umum menyebabkan anak sebagian besar melakukan kenakalan, terutama karena perceraian atau perpisahan orang tua yang sangat mempengaruhi perkembangan sang anak. Dalam broken home pada prinsipnya struktur keluarga sudah tidak lengkap lagi ataupun keluarga yang lengkap namun orang tua memiliki kesibukan masing - masing sehingga tidak memberikan perhatian yang cukup terhadap anak

- Lingkungan sekitar tempat tinggal anak (pengaruh teman pergaulan) 


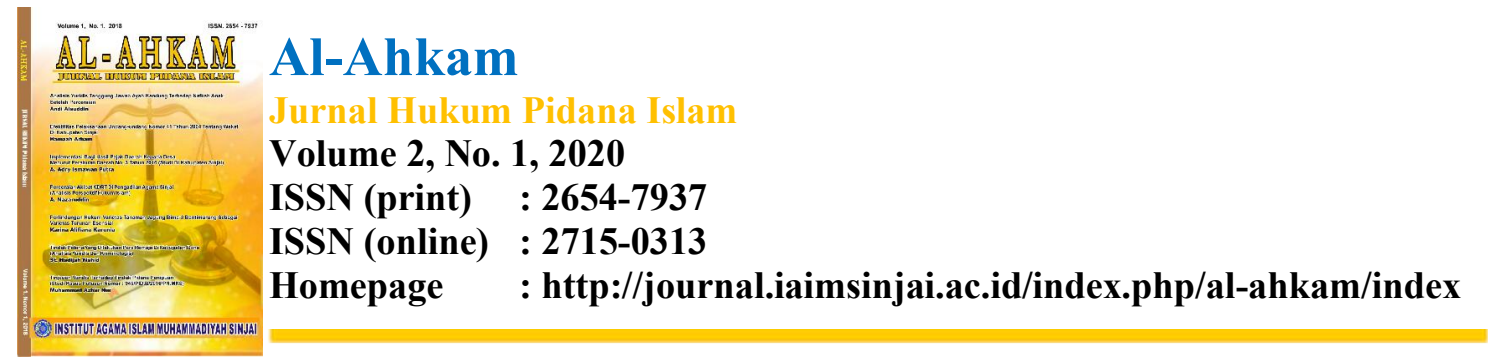

Harus disadari betapa besar pengaruh lingkungan terhadap anak terutama dalam konteks kultural atau kebudayaan lingkungan tersebut. Dalam situasi sosial yang semakin longgar, anak- anak kemudian menegaskan eksistensi dirinya yang dianggap sebagai tersisih atau terancam. Dengan demikian anak menjadi delikuen karena banyak dipengaruhi oleh berbagai tekanan pergaulan yang semuanya memberikan pengaruh yang menekan dan memaksa pada pembentukan perilaku buruk, sebagai produknya anak - anak tadi suka melanggar peraturan, norma sosial, dan hukum formil.

- Pendidikan yang masih kurang (anak termasuk dalam siswa yang nakal / malas disekolah).

Anak - anak yang masuk sekolah ada yang berasal dari keluarga yang tidak begitu memperhatikan kepentingan anak dalam belajar yang kerap kali berpengaruh pada temannya yang lain. Keadaan seperti ini menunjukkan bahwa sekolah merupakan tempat pendidikan anak - anak dapat menjadi sumber terjadinya konflik-konflik psikologis yang pada prinsipnya memudahkan anak menjadi delikuen.

Pelaksaan Perlindungan hukum terhadap anak dalam proses penyidikan tentunya tidak selamanya berjalan sejalan dengan amanat Undang - undan SPPA. Teredapat beberapa kendala yang selalu dihadapai dalam pelaksanaan perlindungan hukum terhadap tersangka anak pada proses penyidikan di Satuan Unit PPA Polres Pohuwato. Adapun beberapa kendala tersebut adalah :

1. Wilayah Kabupaten Pohuwato belum memiliki BAPAS dan Pembimbing Kemasyarakatan, dsb.

Kehadiran Bapas dalam memberikan pendampingan pada tahap penyidikan sangatlah berpengaruh terhadap perlindungan hak anak. Karena Bapas sebagai salah satu pihak yang nantinya akan memberikan pembinaan kepada Anak yang berhadapan dengan hukum

2. Ruang Pelayanan Khusus ( RPK ) belum layak. RPK adalah ruangan yang aman dan nyaman utk khusus saksi dan/atau korban termsk tersangka yang patut diperlakukan atau perlu perlakuan khusus dan perkaranya sdg ditangani Polri.

3. Masih terdapat Penyidik UPPA yg belum mendapat pelatihan khusus.

4. Rutan negara khusus untuk tersangka anak yang sampai saat sekarang ini belum ada.

Penahanan terhadap tersangka anak seharusnya dilakukan di Lingkungan Rutan Negara atau Cabang Rumah Tahanan Negara dan di tempatkan di tempat khusus,serta Penahanan Anak di Jauhkan dari Tahanan Orang dewasa Agar tidak terpengaruh dari masukan- masukan, ajakan, pembelajaran dari Tahanan orang dewasa yang bersifat kriminalisasi.

\section{Simpulan}

Pelaksanaan perlindungan anak sebagai tersangka dalam proses penyidikan di Polres Pohuwato adalah dengan tetap melaksanakan amanat Undang - Undang Sistem Peradilan Anak dan Undang - Undang Perlindungan Anak. Pada tahap penyidikan anak yang melakukan tindak pidana apabila melakukan tindak pidana yang memungkinkan unntuk dilakukan penangkapan dan penahanan maka upaya tersebut akan dilakukan. Dalam proses penyidikan upaya diversi dan ADR akan terus dilaksanakan selama para korban mau memberikan maaf dan menyepakati perdamaian.

Kendala dalam pelaksanaan perlindungan anak sebagai tersangka dalam proses penyidikan di Polres Pohuwato :

- Belum adanya BAPAS di Kabupaten Pohuwato 
- Masih terdapat Penyidik UPPA yg belum mendapat pelatihan khusus.

- Rutan negara khusus untuk tersangka anak yang sampai saat sekarang ini belum ada.

Penelitian ini merekomendasikan pemerintah perlu menyediakan BAPAS dan Pembimbing Kemasyarakatan di wilayah kabupaten Pohuwato agar memudahkan koordinasi dalam pelaksanaan diversi melalui mediasi penal terhadap Anak yang berhadapan dengan hukum. Selain itu sarana dan prasarana khususnya Ruang Pelayanan Khusus ( RPK ) perlu disiapkan dengan segala fasilitas - fasilitas yang mendukung agar tersedianya ruangan yang aman dan nyaman utk khusus saksi dan/atau korban termsk tersangka yang patut diperlakukan atau perlu perlakuan khusus.

\section{Daftar Pustaka}

Abintoro P, (2016), Hukum Perlindungan Anak, Yogyakarta : Laksbang Pressindo.

Arif. G, (1989), Masalah Perlindungan Anak, Jakarta :Akademi Pressindo.

Barda N.A,(1996), Kebijakan Legislatif Dengan Pidana Penjara, Semarang: Badan Penerbit UNDIP.

Irma. S, (1990), Aspek Hukum Perlindungan Anak, Jakarta: Bumi Aksara.

Lili. R \& Ida. B.W.P, (1993), Hukum sebagai suatu sistem Bandung : Remaja Rosdakarya M. Joni \& Zulchaina ZT,(1999), Aspek Hukum Perlindungan Anak dalam Perspektif Konvensi Hak Anak, cet. Ke-I, Bandung : Citra Aditya Bakti

Made. S,(2003), Selayang Pandang Anak sebagai Korban dan Pelaku Tindak Pidana, Malang: Arena Hukum.

Philipus M. H,(1987), Perlindungan Hukum Bagi Rakyat Di Indonesia. Sebuah Studi Tentang Prinsip-prinsipnya. Penanganannya oleh Pengadilan dalam Lingkungan Peradilan Umum dan Pembentukan Peradilan Administrasi Negara, Surabaya : PT. Bina Ilmu.

R Soesilo, (1996), Taktik Dan Teknik Penyidikan Perkara Kriminil, Bogor : Politeia.

\section{Perundang - Undangan}

Undang - Undang RI No 8 Tahun 1981 Tentang Hukum Acara Pidana

Undang -Undang RI Nomor 17 Tahun 2017 Tentang Perubahan Kedua UU Nomor 23 Tahun 2002 Tentang Perlindungan Anak

Undang - Undang RI Nomor 9 Tahun 1999 Tentang Hak Asasi Manusia 